\title{
Prediction of the Granular Materials Strength
}

\author{
Prof. Saad Issa Sarsam*
}

Department of Civil Engineering, College of Engineering, University of Baghdad, Iraq

DOI: $10.36348 /$ sjee.2020.v04i04.002

| Received: 14.06 .2020 | Accepted: 22.06.2020 | Published: 24.06.2020

*Corresponding author: Prof. Saad Issa Sarsam

\section{Abstract}

California bearing ratio (CBR) is an important property used to express the quality and strength of the unbound granular materials. Moreover, it is one of the material inputs for the empirical pavement design procedure. CBR is also conducted on the unbound materials for the quality control/quality assurance during construction. Because of its importance, this paper presents a mathematical approach to the problem of estimating the strength of local sand-aggregate material usually obtained from riverbed and banks and used as subbase layer for road construction. Based on simple and easy to determine physical parameters such as particles size distribution, modified proctor dry density (MDD), and moisture content, such estimation could be determined. The study can help in understanding the nature and the properties of sand-aggregate mixture and provide a reasonable and simple statistical method for assessing the strength from simple physical tests, and assist in considerable reduction of the bulk testing of samples on a project, thus affect economy, choice of material and quality control. The model obtained is capable to explain $73 \%$ of the variation in log CBR predicted from gradation and density parameters.

Keywords: Granular materials; Density; Gradation; Strength; Modeling; Subbase; Bearing.

Copyright @ 2020: This is an open-access article distributed under the terms of the Creative Commons Attribution license which permits unrestricted use, distribution, and reproduction in any medium for non-commercial use (NonCommercial, or CC-BY-NC) provided the original author and source are credited.

\section{INTRODUCTION}

The design of pavement structure is essentially based on the strength characteristics of the sub grade soil and other materials constituting it. The CBR (California bearing ratio) method of pavement design is still commonly adopted to evaluate the strength properties of such materials as reported by UL-Rehman, [1]. Field Engineer responsible for construction of roads have always been on the lookout for a simple method for estimating strength of the subbase layer material which can be easy for adoption and accurate enough for practical purposes, [2]. A review of the available literature about predicting strength value indicates that density, gradation, and index properties have a grate influence on the predicted CBR value [3]. Vinod and Cletus [4] studied the possibility of prediction of CBR values of lateritic soils from the gradation and liquid limit data, while UL-Rehman et al. [5] studied California bearing ratio (CBR) and compaction characteristics of granular soils. An attempt has been made by Taha et al. [6] to develop a simple and reliable CBR model based on routine material properties such as gradation, Atterberg limits and compaction properties using regression analysis. Data of CBR values was collected from the quality control reports. The collected CBR values were found to range between
26 and 98\%. The developed model correlates CBR values with maximum dry density and diameter at $60 \%$ passing (D60). The prediction accuracy in terms of coefficient of determination $\left(\mathrm{R}^{2}\right)$ for the developed CBR model was excellent, and the validation of the suggested model was satisfactory. NCHRP [7], in their assessment, stated the possibility of incorporating the predicted CBR values from soil index properties into the suggested mechanistic empirical design method for pavement structures. Aderinola et al. [8] explored a number of combinations involving the variables of particles size distribution and dry density, they concluded that liquid and plastic limits show no direct visible correction with $\mathrm{CBR}$, and the best trend is seen to be between CBR and dry density for clay soil. Araya et al. [9] stated that characterization of unbound granular road base and subbase materials in developing countries is still done using empirical methods such as California Bearing Ratio (CBR) testing. The CBR does not provide information on the mechanical behavior such as the resilient and permanent deformation characteristics of the material although it is widely applicable. Singh et al. [10] evaluated the CBR of sub grade soil depending on the particle size distribution, dry density, and moisture content. A linear correlation between such variables was developed. Araujo and Ruiz [11] developed the strength index depending on 
the dry density, moisture content, percent sand content and percentage fines for sub grade soil. They concluded that dry density and moisture content are sufficient to identify a group of strength index value. Ahmed et al. [12] stated that in Egypt, California Bearing Ratio $(\mathrm{CBR})$ is the main strength parameter used for characterization of the unbound materials and subgrade soils due to its availability and simplicity. A comprehensive experimental testing program was conducted on different unbound granular base/subbase materials typically used in pavement construction projects in Egypt. The testing program includes Resilient Modulus MR, CBR, and basic material properties. The effect of aggregate gradation on MR is investigated. A model predicting $M R$ as a function of the basic material properties is proposed. The MR-CBR relationship adopted in the current Egyptian Code of Practice is verified based on the testing results. Roy
[13], developed a model for computing soaked CBR values from sieve analysis data for soil, it was concluded that a simple linear expression has been developed for the computation of maximum dry density and soaked CBR value. Esfahani and Goli [14], stated that resilient modulus and California Bearing Ratio (CBR) in unbound granular materials are the key technical characteristics of layers in a flexible pavement design. Among the factors affecting these two parameters, the aggregate gradation is the most important. It was concluded that strength is highest in the lower limit of gradation. Therefore, the use of wellgraded coarse-grained aggregates could significantly increase the strength. Many researchers have developed simple regression equations corelating the CBR value of the soil or granular materials with their physical properties. Table 1 demonstrates such predicted correlations.

Table-1: Predicted models of soil and granular materials strength

\begin{tabular}{|l|l|}
\hline \multicolumn{1}{|c|}{ Model } & \multicolumn{1}{c|}{ Researcher } \\
\hline $\mathrm{CBR}=50.28(\mathrm{MDD})-70.22$ & Bello, $[15]$ \\
\hline $\mathrm{CBR}=21.101(\mathrm{MDD})-30.56$ & Bhatt et al. $[16]$ \\
\hline $\mathrm{CBR}=0.025(\mathrm{P} .200)^{4}+30.130(\mathrm{MDD})-25.813$ & Taha et al. $[17]$ \\
\hline $\mathrm{CBR}=2-16 \log (\mathrm{OMC})+0.07$ L.L & Breytenbach et al. $[18]$ \\
\hline $\mathrm{CBR}=114.7(\mathrm{MDD})-170.57$ & Taha et al. $[19]$ \\
\hline
\end{tabular}

Where:

$\mathrm{CBR}=$ California bearing ratio $(\%)$

MDD = Maximum dry density

P. $200=$ Percent passing sieve No. 200 (75 microns)

OMC $=$ Optimum moisture content

L. L. = Liquid limit (\%)

In Iraq, the local sand-aggregate mixes is readily available at the river banks, and bed either on the surface itself, or at shallow depth; however, quality of this material varies from place to another and thus required to be evaluated as reported by Sarsam, [20].

\section{METHODOLOGY}

The aim of the present investigation is to develop a simple and rapid method for estimating the soaked CBR value for the subbase layer material from gradation analysis and modified proctor density. The methodology presented is based on data on engineering properties collected from the analysis of 80 subbase material samples obtained from various highway projects executed at Mosul city.

\section{Laboratory Investigation}

Sand-aggregate mixture samples were obtained from different highway projects at Mosul city using the standard sampling method as per AASHTO. The samples were obtained from the roadway after spreading the material and before compaction. Samples were subjected to wet grain size analysis [21], modified proctor density test [22], CBR value determination [23] and liquid and plastic limits test as per AASHTO [24].
A total of 80 samples were collected and tested as explained above.

\section{ANALYSIS OF TEST RESULTS AND DISCUSSION}

Analysis of test results was conducted using the stepwise multiple regression analysis software, it shows that the strength characteristics of the material at the soaked condition were influenced by the maximum dry density, optimum moisture content and gradation parameters, therefore, significant correlation could be established, and the mathematical model could be written based on the regression analysis as follows in equation 1. :

$\mathrm{F}(\mathrm{CBR})=\mathrm{A}+\mathrm{a} \mathrm{X}_{1}+\mathrm{bX}_{1}^{2}+\mathrm{c} \mathrm{X}_{2}+\mathrm{dX}_{2}^{2}+\mathrm{eX}_{3}+\mathrm{fX}_{3}^{2}+\mathrm{gX}_{4}$

Where

$\mathrm{F}(\mathrm{CBR})=$ some function of soaked $\mathrm{CBR}$ at $95 \%$ compaction $\mathrm{A}, \mathrm{a}, \mathrm{b}, \mathrm{c}, \mathrm{d}, \mathrm{e}, \mathrm{f}, \mathrm{g}=$ multiple regression analysis constant

$\mathrm{X}_{1}=$ modified maximum dry density $\left(\mathrm{lb} / \mathrm{ft}^{3}\right)$

$\mathrm{X}_{2}=$ optimum moisture content $(\%)$

$\mathrm{X}_{3}, \mathrm{X}_{4}=$ some functions of grain size distribution

The gradation of material was converted into two parameters known as the coefficients of uniformity $(\mathrm{Cu})$ and coefficient of curvature $(\mathrm{Cc})$. Atterberg limits shows no direct visible correlation with $\mathrm{CBR}$, since most of the tested samples were either non-plastic or have very low value of plasticity index (lower than $5 \%$ ), it was felt that such behavior was considered in the low plasticity index requirements of $6 \%$ in the specification as demonstrated in Table 2. 
Table 2: Specification requirements for subbase material-SCRB, [25]

\begin{tabular}{|l|l|l|l|l|}
\hline \multirow{2}{*}{ Sieve size (mm) } & \multicolumn{4}{|c|}{ Percentage finer by weight } \\
\cline { 2 - 5 } & Type A & Type B & Type C & Type D \\
\hline 75 & 100 & 100 & 100 & 100 \\
\hline 50 & $95-100$ & 100 & 100 & 100 \\
\hline 25 & -------- & $75-95$ & 100 & 100 \\
\hline 9.5 & $30-65$ & $40-75$ & $50-85$ & $60-100$ \\
\hline 4.75 & $25-55$ & $30-60$ & $35-65$ & $50-85$ \\
\hline 2.36 & $16-42$ & $21-47$ & $26-52$ & $42-72$ \\
\hline 0.30 & $7-18$ & $14-28$ & $14-28$ & $23-42$ \\
\hline 0.075 & $2-8$ & $5-15$ & $5-15$ & $5-20$ \\
\hline CBR (\%) & ------------ & 35 & 30 & 25 \\
\hline Liquid limit (\%) & 25 & 25 & 25 & 25 \\
\hline Plasticity index (\%) & 6 & 6 & 6 & 6 \\
\hline
\end{tabular}

Numerous multiple regression analysis was conducted to determine the function of CBR that would correlate best with selected form of the variables $X_{1}$, $\mathrm{X}_{2}, \mathrm{X}_{3}, \mathrm{X}_{4}$. Of all the multiple regression analysis investigated, the one that resulted in the highest correlation coefficient was as follows in equation 2 .
$\mathrm{F}(\% \mathrm{CBR})=\log (\% \mathrm{CBR})$

$\mathrm{X}_{1}=$ modified maximum dry density $\left(\mathrm{lb} / \mathrm{ft}^{3}\right)$

$\mathrm{X}_{2}=$ optimum moisture content $(\%)$

$\mathrm{X}_{3}=$ Coefficient of curvature $(\mathrm{Cc})$

$\mathrm{X}_{4}=$ Coefficient of uniformity $(\mathrm{Cu})$

$\mathrm{A}=2.2587 ; \mathrm{a}=-0.019 ; \mathrm{b}=0.00012 ; \mathrm{c}=0.0574 ;$

$\mathrm{d}=0.00371 ; \mathrm{e}=0.00375 ; \mathrm{f}=-0.00003 ; \mathrm{g}=0.00014$

This resulted in the following equation:

$\log (\% \mathrm{CBR})=2.2587-0.019 \mathrm{X}_{1}+0.00012 \mathrm{X}_{1}{ }^{2}-0.0574 \mathrm{X}_{2}+0.00371 \mathrm{X}_{2}{ }^{2}+0.00375 \mathrm{X}_{3}-0.00003 \mathrm{X}_{3}^{2}+0.00014 \mathrm{X}_{4}$

This multiple regression equation resulted in a correlation coefficient $\left(\mathrm{R}^{2}=0.7312\right)$ which means that the equation explains $73 \%$ of the variation in $\log \mathrm{CBR}$. This is further evidenced in that the standard error of estimate (SEE) of $\log \mathrm{CBR}$ is 0.1652. Similar regression models were reported by Shirur, and Hiremath, [26]; Yashas et al., [27]. Figure 1 presents the relationship between observed and predicted CBR values.

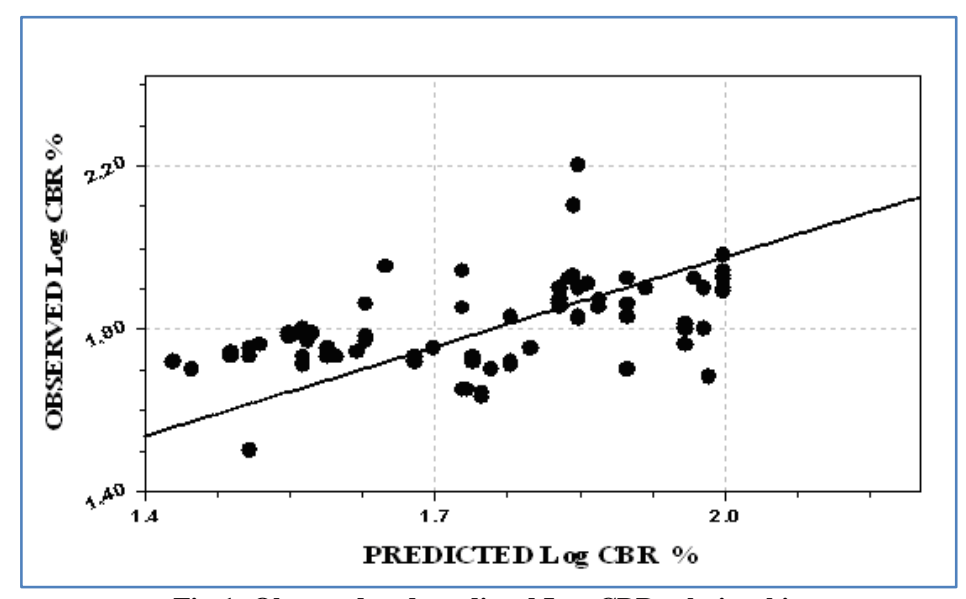

Fig-1: Observed and predicted Log CBR relationship

The figure shows that such values agree quite well and shows considerable scatter about the expected regression line. This, however, is to be expected since the effect of particle shape and roundness may have a marked influence on the strength. Table 3 shows the range of various test results studied.

Table-3: Range of various test results analyzed

\begin{tabular}{|l|l|l|}
\hline Variable & Maximum value & Minimum value \\
\hline \%CBR @ 95\% compaction (AASHTO T-180-74) & 98 & 26 \\
\hline Maximum dry density $\left(\mathrm{lb} / \mathrm{ft}^{3}\right),\left[\mathrm{gm} / \mathrm{cm}^{3}\right]$ & $147,[2.355]$ & $128,[2.051]$ \\
\hline Optimum moisture content $(\%)$ & 8 & 3 \\
\hline Coefficient of uniformity $(\mathrm{Cu})$ & 0.250 & 1733 \\
\hline Coefficient of curvature $(\mathrm{Cc})$ & 0.067 & 115.2 \\
\hline
\end{tabular}




\section{CONCLUSIONS}

Based on the limitations of materials and testing program, the following conclusions may be drawn:

- The strength of the sand-aggregate mix which is usually used for subbase layer construction can be estimated satisfactorily from its physical characteristics by the mathematical approach suggested.

- The soaked CBR value at $95 \%$ compaction obtained on a statistical basis, such as that resulting from the equation presented in this paper should provide a reasonably satisfactory estimate for a given sub base material by comparing this with the difficulty of obtaining a reliable CBR value from a single test.

- Such an approach might possibly be used for estimating the strength of other types of subbase material and assist in considerable reduction of the bulk testing of samples on a project, and thus affect economy, choice of material and quality control.

- The obtained multiple regression model resulted in a correlation coefficient $\left(\mathrm{R}^{2}=0.7312\right)$ which means that the equation explains $73 \%$ of the variation in $\log$ CBR.

\section{REFERENCES}

1. Ul-Rehman, A., Farooq, K., Mujtaba, H., \& Altaf, O. (2015). Estimation of California bearing ratio (CBR) from index properties and compaction characteristics of coarse grained soil. Sci. Int.(Lahore), 27(6), 6207-6210.

2. Abdella, D., Abebe, T., \& Quezon, E. T. (2017). Regression analysis of index properties of soil as strength determinant for California bearing ratio (CBR). GSJ, 5(6), 1.

3. Farias, I. G., Araujo, W., \& Ruiz, G. (2018). Prediction of California bearing ratio from index properties of soils using parametric and nonparametric models. Geotechnical and Geological Engineering, 36(6), 3485-3498.

4. Vinod, P., \& Reena, C. (2008). Prediction of CBR value of lateritic soils using liquid limit and gradation characteristics data. Highway Research Journal, IRC, 1(1), 89-98.

5. Rehman, A. U., Farooq, K., \& Mujtaba, H. (2017). Prediction of California bearing ratio (CBR) and compaction characteristics of granular soils. Acta Geotechnica Slovenica, 14(1), 63-72.

6. Taha, S., Gabr, A., \& El-Badawy, S. (2019). Regression and Neural Network Models for California Bearing Ratio Prediction of Typical Granular Materials in Egypt. Arabian Journal for Science and Engineering, 44(10), 8691-8705.

7. Witczak, M. W., Houston, W. N., \& Zapata, C. E. (2001). Correlation of CBR Values with Soil Index Properties. Development of the 2002 Guide for the Design of New and Rehabilitated Pavement Structures, Technical Report. NCHRP Project.
8. Aderinola, O. S., Oguntoyinbo, E., \& Quadri, A. I. (2017). Correlation of California bearing ratio value of clays with soil index and compaction characteristics. International Journal of Scientific Research and Innovative Technology, 4(4), 12-22.

9. Araya, A., Molenaar, A., \& Houben, L. (2010). Characterization of unbound granular materials using repeated load CBR and triaxial testing. In Paving Materials and Pavement Analysis (pp. 355-363).

10. Singh, D., Reddy, K. S., \& Yadu, L. (2011). Moisture and compaction based statistical model for estimating CBR of fine grained subgrade soils. International Journal of Earth Sciences and Engineering, 4(6), 100-103.

11. Araujo, W., \& Ruiz, G. (2016). Correlation equations of $\mathrm{CBR}$ with index properties of soil in the city of Piura. In Proceeding of 14th LACCEI International Multi-conference for Engineering, Education and Technology (pp. 1-7).

12. El-Ashwah, A. S., Mousa, E., El-Badawy, S. M., \& Abo-Hashema, M. A. (2020). Advanced characterization of unbound granular materials for pavement structural design in Egypt. International Journal of Pavement Engineering, 1-13.

13. Roy, S. (2016). Assessment of soaked California bearing ratio value using geotechnical properties of soils. Resour. Environ, 6(4), 80-87.

14. Aboutalebi Esfahani, M., \& Goli, A. (2018). Effects of aggregate gradation on resilient modulus and CBR in unbound granular materials. International Journal of Transportation Engineering, 5(4), 367-381.

15. Bello, A. A. (2012). Regression analysis between properties of subgrade lateritic soil. Leonardo Journal of Sciences, 11(21), 99-108.

16. Bhatt, S., Jain, P. K., \& Pradesh, M. (2014). Prediction of California bearing ratio of soils using artificial neural network. American International Journal of Research in Science, Technology, Engineering \& Mathematics, 8(2), 156-161.

17. Taha, S., El-Badawy, S., \& Ali, A. (2014). Determination of California bearing ratio through soil index properties. In 4th Jordan International Conference and Exhibition for Roads and Transport (JITC4).

18. Breytenbach, I. J., Paige-Green, P., \& Van Rooy, J. L. (2010). The relationship between index testing and California Bearing Ratio values for natural road construction materials in South Africa. Journal of the South African Institution of Civil Engineering, 52(2), 65-69.

19. Taha, S., El-Badawy, S., Gabr, A., Azam, A., \& Shahdah, U. (2015). Modeling of California bearing ratio using basic engineering properties. In 8th International Engineering Conference, At Sharm Al-Sheikh, Egypt. https://www. researchgate. net/publication/305725330_Modeling_of_Californi 
a_Bearing_Ratio_using_Basic_Engineering_Prope rties.

20. Sarsam S. I. (2010). Assessing the strength of subbase material from physical properties. Proceedings, Second regional conference on engineering science. AL Nahrain University, 1-2 December. Baghdad, Iraq.

21. AASHTO, T. (2014). Standard method of test for sieve analysis of fine and coarse aggregates.

22. AASHTO T 180-18. (2018). Standard Method of Test for Moisture-Density Relations of SoilsUsing a 4.54-kg (10-lb) Rammer and a 457-mm (18-in). Drop moisture-density relations of soils. American society for testing and materials.
23. AASHTO T 193-13. (2017). Standard Method of Test for the California Bearing Ratio, vol. 13. American society for testing and materials.

24. AASHTO T 89-13. (2017). Standard Method of Test for Determining the Liquid Limit of Soils, vol. 13. American society for testing and materials.

25. SCRB. (2003). Standard specification for road and bridges. State commission for roads and bridges, Ministry of housing and construction, Iraq.

26. Shirur, N. B., \& Hiremath, S. G. (2014). Establishing relationship between CBR value and physical properties of soil. IOSR journal of mechanical and civil engineering, 11(5), 26-30.

27. Yashas, S. R., \& Harish, S. N. (2016). Muralidhara: Effect of California bearing ratio on the properties of soil. Am. J. Eng. Res.(AJER), 5(4), 28-37. 